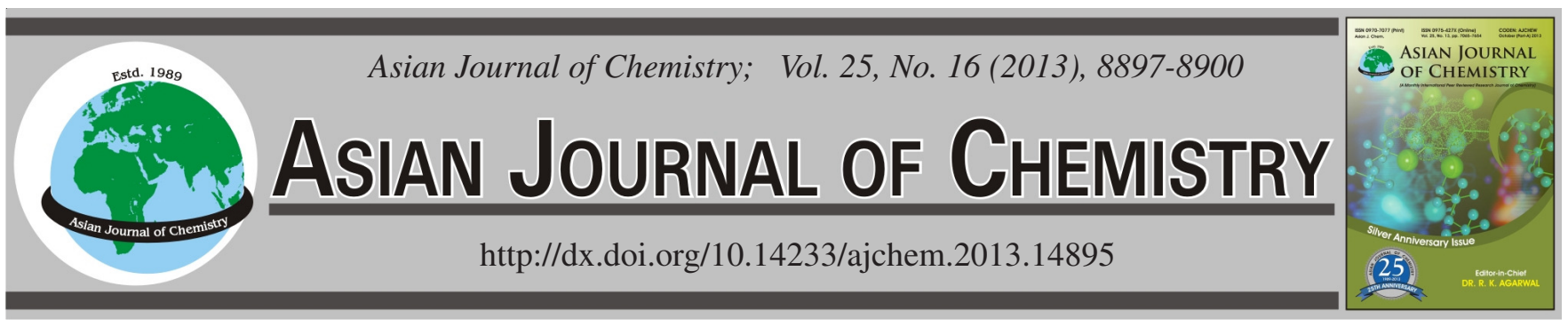

\title{
Synthesis of New Strobilurin Derivatives with Modified 1,3,5-Triazine Moiety
}

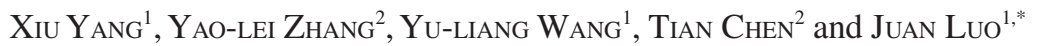

${ }^{1}$ College of Chemistry, Sichuan University, Chengdu 610065, P.R. China

${ }^{2}$ Department of Pathogenic Biology, School of Biomedical Science, Chengdu Medical College, Chengdu 610083, P.R. China

*Corresponding author: Tel: +86 18980715296, E-mail: loyis-luo@163.com

(Received: 3 December 2012;

Accepted: 5 September 2013)

AJC-14075

\begin{abstract}
A new procedure for the synthesis of a series of strobilurin derivatives is reported. The new compounds bear the 1,3,5-triazine ring structure and can be used as the potential fungicide. All target compounds had been identified by ${ }^{1} \mathrm{H}$ NMR spectrum, IR spectrum and HRMS. The results of antifungal activities showed that all target compounds exhibited antifungal activities against three fungus strains at the concentration $20 \mu \mathrm{g} / \mathrm{mL}$.

Key Words: Synthesis, Strobilurin derivatives, 1,3,5-Triazine ring, Antifungal activities.
\end{abstract}

\section{INTRODUCTION}

Strobilurin A (Fig. 1, 1) $)^{1,2}$, a naturally occurring antibiotic, was first isolated from Oudemansiella mucida in 1969. It was found that its application in agriculture was limited because of optical instability ${ }^{3}$. Early 1980s, groups in Syngenta and $\mathrm{BASF}^{3,4}$ began to alter the structure of strobilurins. In the new designed structure methyl (E)-2-(3-methoxy)acrylate moiety was retained as active part and benzene ring was used to replace the unstable polyene moiety, then a series of strobilurin analogues against fungus with optimum stability were synthe-sized ${ }^{2-5}$. Studies showed that the strobilurin derivatives acted on the respiration process by interrupting the electron transport ${ }^{6}$.<smiles>COC=C(C)C(=COC)C(=O)OC</smiles><smiles>CO/C=C(/OC)c1ccccc1Oc1cc(Oc2ccccc2C#N)ncn1</smiles>

Azoxystrobin 2<smiles>CO/C=C(/OC)c1ccccc1CO/N=C(C)/C=C/c1ccc(Cl)cc1</smiles>

Enestroburin 4

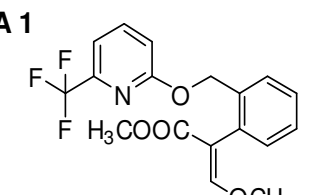

Picoxystrobin $3 \mathrm{OCH}_{3}$<smiles>CO/C=C(/OC)c1ccccc1COc1cc(-c2ccc(Cl)cc2)nn1C</smiles>

Fig. 1. Structure of strobilurins and related derivaties
It could be found in the literatures ${ }^{7,8}$ that the structure of the strobilurin derivatives was composed of the active group, bridge and side chain. (Fig. 2) Changes in the structure of the derivatives involved the active group and side chain, the derivatives with methyl (E)-2-(3-methoxy)acrylate had shown good fungicidal activity ${ }^{9,10}$. The derivatives modified in the side chain were used as high-efficiency and broad-spectrum fungicides ${ }^{11-13}$.

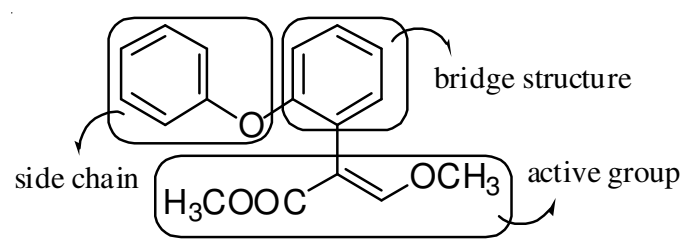

Fig. 2. Activity structure of the strobilurins

Based on these structure-activity relationships, large numbers of derivatives had been designed and synthesized. As a result, azoxystrobin (Fig. 1, 2) ${ }^{14}$ and picoxystrobin (Fig.1, 3) ${ }^{6}$ were developed as broad-spectrum fungicides with activity against the four major groups of plant pathogenic fungus including Ascomycetes, Basidiomycetes, Deuteromycetes and Oomycetes. Up to now, azoxystrobin has been the top sale of fungicide for agricultural use in the world ${ }^{3}$. Recently Shenyang Chemical Research Institute reported the new strobilurin analogues enestroburin (Fig.1, 4) and pyraoxystrobin (Fig.1, 5) ${ }^{2}$, which exhibited good fungicidal activity on a wide range of crops $^{15}$.

Aiming to obtain potential drug molecules, a series of compounds with the 1,3,5-triazine ring structure, which has 


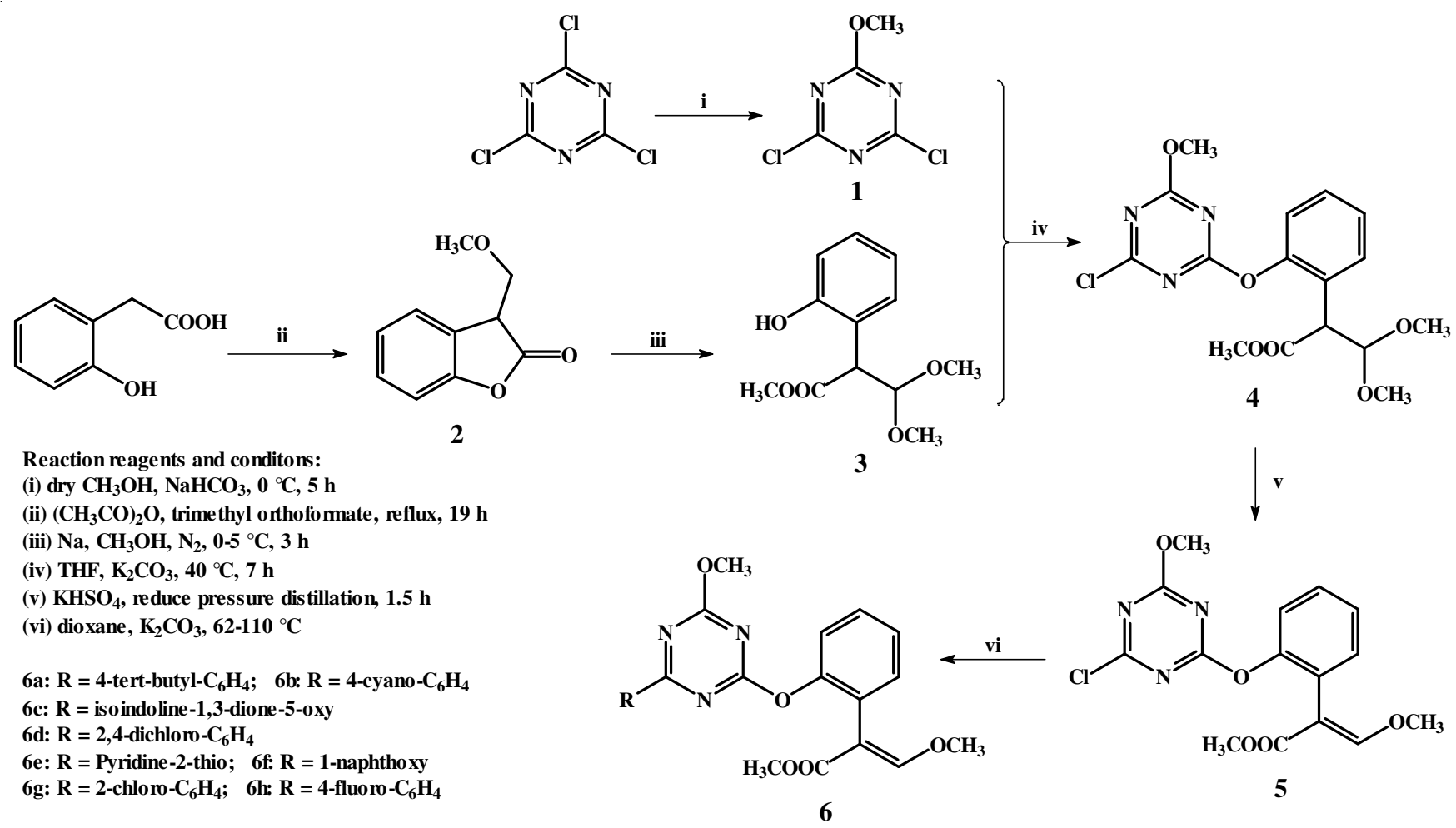

Scheme-I: Synthetic route of compound $\mathbf{6 a - h}$

wide range of biological activity and multiple reaction sites, were designed and synthesized. In addition, phenol with different kinds of substituted groups were introduced to study whether the groups is useful to bioactivity. The synthetic route is shown in Scheme-I.

\section{EXPERIMENTAL}

Melting points were determined with XRC-1 melting point apparatus without corrected. Analytical TLC was performed on silica gel $\mathrm{GF}_{254}$ and spots were visualized with ultraviolet light. IR spectra were recorded on a Perkin-Elemer 16PC-FT spectrometer. Mass spectra were recorded with Agilent 6210 (DOF-MAS) spectrometer (Agilent Inc., Santa Clara, CA, USA) using the electrospray ionization $\left(\mathrm{ESI}^{+}\right)$ method. ${ }^{1} \mathrm{H}$ NMR spectra were run on a Varian INVOA-400 spectrometer. The reagents were all analytically or chemically pure. All solvents were dried with anhydrous $\mathrm{Na}_{2} \mathrm{SO}_{4}$ and distillated.

Compound 1 was synthesized according to the literature ${ }^{16}$; Compound 2 was synthesized according to the literature ${ }^{17}$.

Synthesis of compound 3: Metallic sodium (150 mmol, $3.45 \mathrm{~g}$ ) was added in portions to absolute methanol $(100 \mathrm{~mL})$ in single-necked round bottom flask and the result mixture was stirred at room temperature until metallic sodium was dissolved completely, then compound 2 (50 mmol, $8.8 \mathrm{~g})$ in dry methanol $(20 \mathrm{~mL})$ was added dropwise to the suspension at the atmosphere of nitrogen, the mixture was stirred at $0{ }^{\circ} \mathrm{C}$ for $5 \mathrm{~h}$ and then acidified with ice acetic acid to $\mathrm{pH}=6$ at about $-15^{\circ} \mathrm{C}$, diluted with water $(120 \mathrm{~mL})$, extracted with $\mathrm{CH}_{2} \mathrm{Cl}_{2}(30 \mathrm{~mL} \times 3)$. The $\mathrm{CH}_{2} \mathrm{Cl}_{2}$ layer was combined and washed with saturated sodium bicarbonate solution $(10 \mathrm{~mL} \times$ $3)$ and water $(10 \mathrm{~mL} \times 3)$, dried with anhydrous sodium sulfate overnight, evaporated under reduced pressure at $10^{\circ} \mathrm{C}$ to afford a deep red oil, crude yield: $82 \%$. Compound 3 was used in the next reaction without further purification.

Synthesis of compound 4: A solution of compound $\mathbf{1}$ (20 mmol, $4.76 \mathrm{~g})$ in dry THF $(20 \mathrm{~mL})$ was added to a suspension of compound 3 (22 mmol, $3.96 \mathrm{~g}$ ) and $\mathrm{K}_{2} \mathrm{CO}_{3}(20 \mathrm{mmol}$, $2.76 \mathrm{~g})$ in dry THF $(30 \mathrm{~mL})$. The reaction mixture was stirred at $40^{\circ} \mathrm{C}$ for $7 \mathrm{~h}$, then cooled to room temperature and filtered. The filtrate was evaporated under reduced pressure and the resulting residue was taken up with dichloromethane $(20 \mathrm{~mL})$, the organic layer was washed with water $(10 \mathrm{~mL} \times 3)$, dried with anhydrous $\mathrm{Na}_{2} \mathrm{SO}_{4}$ and evaporated under reduced pressure to give the crude product. The crude product was chromatographed on silica gel (petroleum ether: ethyl acetate $=2: 1$ ) to afford a pure product as a yellow solid, yield: $71 \%$.

Synthesis of compound 5: A catalytic amount of potassium bisulfate (1 mmol) and compound 4 (10 mmol, $3.63 \mathrm{~g}$ ) were distillated at $100{ }^{\circ} \mathrm{C}$ under $5 \mathrm{~mm} \mathrm{Hg}$ pressure whilst determined by TLC, then cooled to room temperature, extracted with $\mathrm{CH}_{2} \mathrm{Cl}_{2}(20 \mathrm{~mL})$ and filtered. The filtrate was washed with water $(10 \mathrm{~mL} \times 3)$, dried and concentrated to give the crude compound $\mathbf{5}$. Recrystallization from cyclohexane gave a pale yellow solid, yield: $62 \%$.

Synthesis of target compounds 6a-h: Compound 5 (1 $\mathrm{mmol}, 0.34 \mathrm{~g})$ in dry dioxane $(10 \mathrm{~mL})$ was added dropwise to a suspense of substituted phenol $(1.1 \mathrm{mmol})$ and $\mathrm{K}_{2} \mathrm{CO}_{3}(1.1$ mmol, $0.15 \mathrm{~g})$ in dry dioxane $(10 \mathrm{~mL})$ with stirring. The reaction mixture was heated to reflux and maintained for $7 \mathrm{~h}$, then cooled to room temperature and filtered. The filtrate was evaporated under reduced pressure to give the crude product. The crude product was chromatographed using petroleum ether and ethyl acetate as eluent to afford the target products $\mathbf{6 a - h}$. 


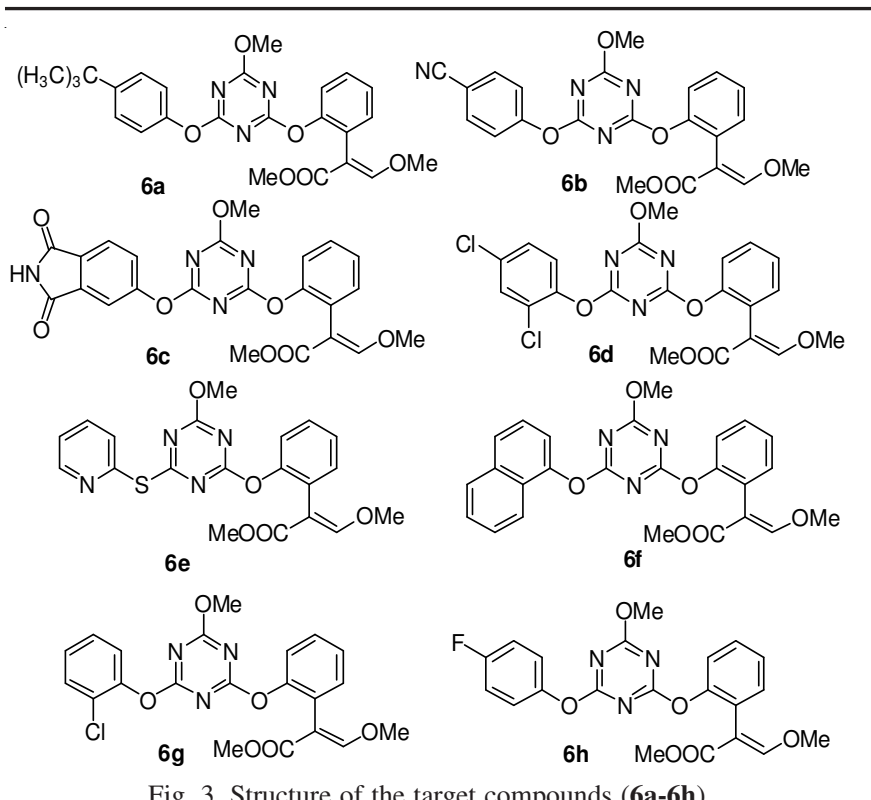

Fig. 3. Structure of the target compounds $(\mathbf{6 a}-\mathbf{6 h})$

(E)-methyl 2-\{2-[4-(4-tert-butylphenoxy)-6-methoxy1,3,5-triazin-2-yloxy]phenyl $\}$-3-methoxyacrylate (6a): Yellow solid; yield: $64 \%$; m.p.: $128-130{ }^{\circ} \mathrm{C} ;{ }^{1} \mathrm{H}$ NMR (400 $\mathrm{MHz} ; \mathrm{d}_{1}-\mathrm{CDCl}_{3}$; TMS): $\delta$ (ppm): 7.47 (s, $\left.1 \mathrm{H}, \mathrm{C}=\mathrm{C}-\mathrm{H}\right), 7.36$ $(\mathrm{d}, 2 \mathrm{H}, J=8.8 \mathrm{~Hz}, \mathrm{Ar}-\mathrm{H}), 7.31(\mathrm{~d}, 2 \mathrm{H}, J=8.0 \mathrm{~Hz}, \mathrm{Ar}-\mathrm{H})$, 7.25 7.19 (m, 2H, Ar-H), 7.06 (d, 2H, J=8.8 Hz, Ar-H), 3.90 $\left(\mathrm{s}, 3 \mathrm{H}, \mathrm{CH}_{3}\right), 3.76\left(\mathrm{~s}, 3 \mathrm{H}, \mathrm{CH}_{3}\right), 3.63\left(\mathrm{~s}, 3 \mathrm{H}, \mathrm{CH}_{3}\right), 1.32(\mathrm{~s}, 9 \mathrm{H}$, $\left.\mathrm{C}\left(\mathrm{CH}_{3}\right)_{3}\right)$; IR $\left(\mathrm{KBr}, \mathrm{cm}^{-1}\right) 2954(\mathrm{C}=\mathrm{C}-\mathrm{H}), 1705(\mathrm{C}=\mathrm{O}), 1638$ $(\mathrm{C}=\mathrm{C}), 1564(\mathrm{Ph}), 1377(\mathrm{C}-\mathrm{N}), 1216$ [C( $\left.\left(\mathrm{CH}_{3}\right)_{3}\right], 1119$ (C-OC), $817(\mathrm{Ph}-\mathrm{H})$; HR-MS (ESI ${ }^{+}$): Calcd. for $\mathrm{C}_{25} \mathrm{H}_{28} \mathrm{~N}_{3} \mathrm{O}_{6}[\mathrm{M}+\mathrm{H}]^{+}$: 466.1978, Found: 466.1976.

(E)-methyl 2-\{2-[4-(4-cyanophenoxy)-6-methoxy1,3,5-triazin-2-yloxy]phenyl\}-3-methoxyacrylate (6b): Yellow solid; yield: $50 \%$; m.p.: 106-108 ${ }^{\circ} \mathrm{C}$; ${ }^{1} \mathrm{H}$ NMR(400 $\mathrm{MHz} ; \mathrm{d}_{1}-\mathrm{CDCl}_{3}$; TMS): $\delta$ (ppm): $7.67(\mathrm{~d}, 2 \mathrm{H}, J=8.4 \mathrm{~Hz}$, Ar-H), 7.47 (s, 1H, C=C-H), 7.36 7.26 (m, 5H, Ar-H), 7.19 $(\mathrm{d}, 1 \mathrm{H}, J=8.0 \mathrm{~Hz}, \mathrm{Ar}-\mathrm{H}), 3.92\left(\mathrm{~s}, 3 \mathrm{H}, \mathrm{CH}_{3}\right), 3.77$ (s, 3H, $\mathrm{CH}_{3}$ ), 3.62 (s, 3H, $\mathrm{CH}_{3}$ ); IR (KBr, cm $\left.{ }^{-1}\right) 3053$ (Ar-H), 2953 $(\mathrm{C}=\mathrm{C}-\mathrm{H}), 2231(\mathrm{CN}), 1707(\mathrm{C}=\mathrm{O}), 1639(\mathrm{C}=\mathrm{C}), 1577(\mathrm{Ph})$, 1216, 1078 (C-O-C); HR-MS (ESI ${ }^{+}$): Calcd. for $\mathrm{C}_{22} \mathrm{H}_{19} \mathrm{~N}_{4} \mathrm{O}_{6}$ $[\mathrm{M}+\mathrm{H}]^{+}:$435.1304, Found: 435.1305.

(E)-methyl 2-\{2-[4-(isoin-1,3-dione5-hydroxyl)-6methoxy-1,3,5-triazin-2-yloxy]phenyl\}-3-methoxyacrylate (6c): Yellow solid; yield: $52 \%$; m.p.: $192-194{ }^{\circ} \mathrm{C} ;{ }^{1} \mathrm{H}$ NMR (400 MHz; $\mathrm{d}_{1}-\mathrm{CDCl}_{3}$; TMS): $\delta$ (ppm): $7.80(\mathrm{~d}, 1 \mathrm{H}, J=8.0 \mathrm{~Hz}$, Ar-H), 7.70 (s, 1H, NH), $7.54 \sim 7.49$ (m, 2H, Ar-H), 7.47 (s, $1 \mathrm{H}, \mathrm{C}=\mathrm{C}-\mathrm{H}), 7.35 \sim 7.27$ (m, 3H, Ar-H), 7.17 (d, 1H, J = 8.0 $\mathrm{Hz}, \mathrm{Ar}-\mathrm{H}), 3.92$ (s, 3H, CH 3$), 3.77$ (s, 3H, $\left.\mathrm{CH}_{3}\right), 3.63$ (s, 3H, $\left.\mathrm{CH}_{3}\right)$; IR $\left(\mathrm{KBr}, \mathrm{cm}^{-1}\right) 3268(\mathrm{~N}-\mathrm{H}), 3071(\mathrm{Ar}-\mathrm{H}), 2951(\mathrm{C}=\mathrm{C}-$ $\mathrm{H}), 1716(\mathrm{C}=\mathrm{O}), 1611(\mathrm{C}=\mathrm{C}), 1555(\mathrm{Ph}), 1360(\mathrm{C}-\mathrm{N}), 1260$, 1124 (C-O-C); HR-MS (ESI ${ }^{+}$): Calcd. for $\mathrm{C}_{23} \mathrm{H}_{19} \mathrm{~N}_{4} \mathrm{O}_{8}[\mathrm{M}+\mathrm{H}]^{+}$: 479.1203, Found: 479.1200.

(E)-methyl 2-\{2-[4-(2,4-dichlorophenoxy)-6-methoxy1,3,5-triazin-2-yloxy]phenyl\}-3-methoxyacrylate $(6 \mathrm{~d})$ : Yellow solid; yield: $42 \%$; m.p.: 74-76 ${ }^{\circ} \mathrm{C} ;{ }^{1} \mathrm{H}$ NMR (400 MHz; $\mathrm{d}_{1}-\mathrm{CDCl}_{3}$; TMS): $\delta$ (ppm): $7.47(\mathrm{~s}, 1 \mathrm{H}, \mathrm{C}=\mathrm{C}-\mathrm{H}), 7.34 \sim 7.27$ (m, 4H, Ar-H), 7.23 7.19 (m, 2H, Ar-H), 7.14 (d, 1H, J= 8.4 $\mathrm{Hz}, \mathrm{Ar}-\mathrm{H}), 3.93$ (s, 3H, $\left.\mathrm{CH}_{3}\right), 3.76$ (s, 3H, $\left.\mathrm{CH}_{3}\right), 3.63$ (s, 3H, $\left.\mathrm{CH}_{3}\right)$; IR $\left(\mathrm{KBr}, \mathrm{cm}^{-1}\right) 3068(\mathrm{Ar}-\mathrm{H}), 2950(\mathrm{C}=\mathrm{C}-\mathrm{H}), 1710$
$(\mathrm{C}=\mathrm{O}), 1635(\mathrm{C}=\mathrm{C}), 1558(\mathrm{Ph}), 1363(\mathrm{C}-\mathrm{N}), 1256,1126(\mathrm{C}-$ O-C), $765(\mathrm{C}-\mathrm{Cl})$; HR-MS (ESI $\left.{ }^{+}\right)$: Calcd. for $\mathrm{C}_{21} \mathrm{H}_{18} \mathrm{~N}_{3} \mathrm{O}_{6} \mathrm{Cl}_{2}$ $[\mathrm{M}+\mathrm{H}]^{+}$: 478.0572, Found: 478.0568 .

(E)-methyl 2-\{2-[4-methoxy-6-(pyridin-2-ylthio)-1,3,5triazin-2-yloxy]phenyl\}-3-methoxyacrylate (6e): Yellow solid; yield: $76 \%$; m.p.: 48-50 ${ }^{\circ} \mathrm{C}$; ${ }^{1} \mathrm{H}$ NMR (400 MHz; $\mathrm{d}_{1-}$ $\mathrm{CDCl}_{3}$; TMS): $\delta$ (ppm): $8.55(\mathrm{~d}, 1 \mathrm{H}, J=8.0 \mathrm{~Hz}, \mathrm{Py}-\mathrm{H}), 7.66$ (d, 1H, $J=8.0 \mathrm{~Hz}, \mathrm{Py}-\mathrm{H}), 7.54 \sim 7.50(\mathrm{~m}, 1 \mathrm{H}, \mathrm{Py}-\mathrm{H}), 7.46$ (s, $1 \mathrm{H}, \mathrm{C}=\mathrm{C}-\mathrm{H}), 7.30 \sim 7.20(\mathrm{~m}, 4 \mathrm{H}, \mathrm{Ar}-\mathrm{H}), 7.12-7.09(\mathrm{~m}, 1 \mathrm{H}$, Ar-H), 3.89 (s, 3H, $\left.\mathrm{CH}_{3}\right), 3.74$ (s, 3H, $\left.\mathrm{CH}_{3}\right), 3.61$ (s, 3H, $\left.\mathrm{CH}_{3}\right)$; IR $\left(\mathrm{KBr}, \mathrm{cm}^{-1}\right) 2947(\mathrm{C}=\mathrm{C}-\mathrm{H}), 1709(\mathrm{C}=\mathrm{O}), 1635(\mathrm{C}=\mathrm{C}), 1546$ (Ph), 1352 (C-N), 1128 (C-O-C); HR-MS (ESI ${ }^{+}$): Calcd. for $\mathrm{C}_{20} \mathrm{H}_{19} \mathrm{~N}_{4} \mathrm{O}_{5} \mathrm{~S}[\mathrm{M}+\mathrm{H}]^{+}$: 427.1076, Found: 427.1078.

(E)-methyl 2-\{2-[4-methoxy-6-(naphthalen-1-yloxy)1,3,5-triazin-2-yloxy]phenyl\}-3-methoxyacrylate (6f): White solid; yield: $64 \%$; m.p.: 146-148 ${ }^{\circ} \mathrm{C}$; ${ }^{1} \mathrm{H}$ NMR (400 $\mathrm{MHz} ; \mathrm{d}_{1}-\mathrm{CDCl}_{3}$; TMS): $\delta$ (ppm): 7.89 7.86 (m, 2H, Ar-H), $7.76(\mathrm{~d}, 1 \mathrm{H}, J=8.0 \mathrm{~Hz}, \mathrm{Ar}-\mathrm{H}), 7.52 \sim 7.43$ (m, 4H, Ar-H, C=CH), $7.32 \sim 7.22(\mathrm{~m}, 4 \mathrm{H}, \mathrm{Ar}-\mathrm{H}), 7.16(\mathrm{~d}, 1 \mathrm{H}, J=8.0 \mathrm{~Hz}, \mathrm{Ar}-\mathrm{H})$, 3.83 (s, 3H, $\mathrm{CH}_{3}$ ), 3.67 (s, 3H, $\left.\mathrm{CH}_{3}\right), 3.62$ (s, 3H, $\left.\mathrm{CH}_{3}\right)$; IR $\left(\mathrm{KBr}, \mathrm{cm}^{-1}\right) 2953(\mathrm{C}=\mathrm{C}-\mathrm{H}), 1703(\mathrm{C}=\mathrm{O}), 1629(\mathrm{C}=\mathrm{C}), 1551$ (Ph), 1125 (C-O-C), 787 (Ph-H); HR-MS (ESI $)$ : Calcd. for $\mathrm{C}_{25} \mathrm{H}_{22} \mathrm{~N}_{3} \mathrm{O}_{6}[\mathrm{M}+\mathrm{H}]^{+}: 460.1508$, Found: 460.1510 .

(E)-methyl 2-\{2-[4-(2-chlorophenoxy)-6-methoxy1,3,5-triazin-2-yloxy]phenyl $\}-3-$ methoxyacrylate $(6 \mathrm{~g})$ : White solid; yield: $57 \%$; m.p.: 106-108 ${ }^{\circ} \mathrm{C}$; ${ }^{1} \mathrm{H}$ NMR (400 MHz; $\mathrm{d}_{1}-\mathrm{CDCl}_{3}$; TMS): $\delta$ (ppm): 7.48 7.33 (m, 2H, Ar-H, $\mathrm{C}=\mathrm{C}-\mathrm{H}), 7.39 \sim 7.29$ (m, 3H, Ar-H), 7.28 7.25 (m, 2H, Ar-H), $7.23 \sim 7.14$ (m, 2H, Ar-H), 3.90 (s, 3H, $\left.\mathrm{CH}_{3}\right), 3.75\left(\mathrm{~s}, 3 \mathrm{H}, \mathrm{CH}_{3}\right)$, $3.63\left(\mathrm{~s}, 3 \mathrm{H}, \mathrm{CH}_{3}\right)$; IR $\left(\mathrm{KBr}, \mathrm{cm}^{-1}\right) 2951(\mathrm{C}=\mathrm{C}-\mathrm{H}), 1711(\mathrm{C}=\mathrm{O})$, 1634 (C=C), 1564 (Ph), 1120 (C-O-C), $812(\mathrm{Ph}-\mathrm{H}), 767$ (C$\mathrm{Cl}$ ); HR-MS $\left(\mathrm{ESI}^{+}\right)$: Calcd. for $\mathrm{C}_{21} \mathrm{H}_{19} \mathrm{~N}_{3} \mathrm{O}_{6} \mathrm{Cl}[\mathrm{M}+\mathrm{H}]^{+}$: 444.0962, Found: 444.0967.

(E)-methyl 2-\{2-[4-(4-fluorophenoxy)-6-methoxy1,3,5-triazin-2-yloxy]phenyl $\}-3$-methoxyacrylate $(6 \mathrm{~h})$ : Yellow solid; yield: $52 \%$; m.p.: $130-132{ }^{\circ} \mathrm{C} ;{ }^{1} \mathrm{H}$ NMR (400 $\mathrm{MHz} ; \mathrm{d}_{1}-\mathrm{CDCl}_{3}$; TMS): $\delta(\mathrm{ppm}): 7.46(\mathrm{~s}, 1 \mathrm{H}, \mathrm{C}=\mathrm{C}-\mathrm{H})$, 7.35 7.27 (m, 3H, Ar-H), $7.18(\mathrm{~d}, 1 \mathrm{H}, J=8.0 \mathrm{~Hz}, \mathrm{Ar}-\mathrm{H})$, 7.13 7.02 (m, 4H, Ar-H), 3.89 (s, 3H, $\left.\mathrm{CH}_{3}\right), 3.76$ (s, 3H, $\left.\mathrm{CH}_{3}\right)$, $3.62\left(\mathrm{~s}, 3 \mathrm{H}, \mathrm{CH}_{3}\right)$; IR $\left(\mathrm{KBr}, \mathrm{cm}^{-1}\right) 2950(\mathrm{C}=\mathrm{C}-\mathrm{H}), 1710(\mathrm{C}=\mathrm{O})$, 1633 (C=C), 1570 (Ph), 1252 (Ph-O-C), 1123 (C-O-C), 1054 (C-F), 810 (Ph-H); HR-MS (ESI ${ }^{+}$): Calcd. for $\mathrm{C}_{21} \mathrm{H}_{19} \mathrm{~N}_{3} \mathrm{O}_{6} \mathrm{~F}$ $[\mathrm{M}+\mathrm{H}]^{+}:$428.1258, Found: 428.1261.

Biological assay: The antifungal activities of the target compounds in vitro were tested via an Oxford cup method. Target compounds $(1000 \mu \mathrm{g})$ were dissolved with DMSO (1 $\mathrm{mL}$ ) and diluted to $20.0 \mu \mathrm{g} / \mathrm{mL}$ with $\mathrm{H}_{2} \mathrm{O}$. A $150 \mu \mathrm{L}$ solution of each compound was injected into the corresponding cup in the potato, dextrose and agar (PDA) culture medium which was covered with fungus suspension in advance and the plates were incubated at $37^{\circ} \mathrm{C}$ for $48 \mathrm{~h}$. The results of average diameters of the inhibition zone were listed in Table- 1.

\section{RESULTS AND DISCUSSION}

Synthesis: In the synthesis of intermediate 1, three chlorine atoms of cyanuric chloride could be replaced at $0-5{ }^{\circ} \mathrm{C}$, $30-40{ }^{\circ} \mathrm{C}$, above $60{ }^{\circ} \mathrm{C}$. So the temperature was a key factor and should be controlled below $5^{\circ} \mathrm{C}$. 
TABLE-1

in vitro THE ANTIFUNGAL ACTIVITY OF THE TARGET COMPOUNDS AT THE CONCENTRATION OF $20 \mu \mathrm{g} / \mathrm{mL}$

\begin{tabular}{|c|c|c|c|}
\hline \multirow[b]{2}{*}{ Compound } & \multicolumn{3}{|c|}{ Diameter of inhibition zone (mm) } \\
\hline & $\begin{array}{c}\text { Aspergillus } \\
\text { niger }\end{array}$ & $\begin{array}{l}\text { Magnaporthe } \\
\text { grisea }\end{array}$ & $\begin{array}{c}\text { Aspergillus } \\
\text { oryzae }\end{array}$ \\
\hline $6 a$ & 11 & 8 & 8 \\
\hline $6 b$ & 12 & 12 & 8 \\
\hline $6 \mathrm{c}$ & 9 & 10 & 13 \\
\hline $6 d$ & 10 & 11 & 8 \\
\hline $6 e$ & 14 & 10 & 9 \\
\hline $6 f$ & 8 & 8 & 12 \\
\hline $6 g$ & 8 & 11 & 10 \\
\hline $6 \mathrm{~h}$ & 8 & 8 & 8 \\
\hline $\mathrm{DMSO}^{\mathrm{a}}$ & 7 & 7 & 7 \\
\hline
\end{tabular}

The synthesis of intermediate $\mathbf{3}$ included the transesterification reaction and the carbon-carbon double bond addition reaction. In order to reduce the side products, sodium methoxide should be freshly prepared and the system should be protected with nitrogen. In addition, post-processing was also at low temperatures, the solvent methylene chloride was distillated below $15^{\circ} \mathrm{C}$ under reduced pressure, or side-products came up.

In the synthesis of intermediate $\mathbf{4}$, compound $\mathbf{3}$ reacted with $\mathrm{K}_{2} \mathrm{CO}_{3}$ to form potassium salt at room temperature. The replacing temperature was controlled at $30-40{ }^{\circ} \mathrm{C}$ due to the unstability of acetal structure of intermediate 3 .

For the synthesis of intermediate $\mathbf{5}$, double bond was formed by distillation under reduced pressure with $\mathrm{KHSO}_{4}$ as catalyst.

In the synthesis of target compounds, taking into account the reactivity of intermediate $\mathbf{5}$ and the reaction temperature, dioxane was the best choice as polar aprotic solvent. In order to complete the reaction rapidly and decrease by-products, dioxane should be dried thoroughly and distilled in advance. The different structures of phenol have different reactivity in the reaction process, the reaction conditions required are also different, (Table-2) and reaction rule as follows:

\begin{tabular}{ccccc}
\multicolumn{6}{c}{ TABLE-2 } \\
\multicolumn{6}{c}{ REACTION CONDITION OF THE TARGET COMPOUNDS $(\mathbf{6 a - 6 h})$} \\
\hline Compound & Temperature $\left({ }^{\circ} \mathrm{C}\right)$ & Time $(\mathrm{h})$ & Catalyst & Yield $(\%)$ \\
\hline $\mathbf{6 a}$ & 90 & 7 & - & 64 \\
$\mathbf{6 b}$ & 90 & 7 & KI & 50 \\
$\mathbf{6 c}$ & 90 & 7 & KI & 52 \\
$\mathbf{6 d}$ & 110 & 9 & KI & 42 \\
$\mathbf{6 e}$ & 60 & 5 & - & 76 \\
$\mathbf{6 f}$ & 90 & 7 & - & 64 \\
$\mathbf{6 g}$ & 90 & 7 & - & 57 \\
$\mathbf{6 h}$ & 90 & 7 & - & 52 \\
\hline
\end{tabular}

1) The reactivity of thiophenol was higher than reactivity of phenol, for example, 2-mercapto pyridine reacted with intermediate 5 at $60^{\circ} \mathrm{C}$ and without catalyst, but other phenols at $90{ }^{\circ} \mathrm{C}$.

2) The reactivity of the phenol with electron donating group is higher than the ones with electron withdrawing group; For example, tert-butylphenol, naphthol reacted at $90^{\circ} \mathrm{C}$, while the cyano phenol and heterocyclic phenol must react with the catalyst KI together.

3) The steric effects 2,4-dichlorophenol reacted more difficult than the mono-substituted phenol, which reacted with KI at $110^{\circ} \mathrm{C}$.

Biological activity: The results of antifungal activities showed that all target compounds exhibited antifungal activities against three fungus strains (Aspergillus niger, Magnaporthe grisea and Aspergillus oryzae) at the concentration $20 \mu \mathrm{g} / \mathrm{mL}$.

\section{Conclusion}

In summary, a series of novel strobilurin derivatives with modified 1,3,5-triazine moiety had been designed and synthesized. All target compounds had been identified by ${ }^{1} \mathrm{H}$ NMR spectrum, IR spectrum and HR-MS (high resolution mass spectrum). The results of antifungal activities showed that all target compounds exhibited antifungal activities against three fungus strains at the concentration $20 \mu \mathrm{g} / \mathrm{mL}$.

\section{ACKNOWLEDGEMENTS}

The authors appreciated the financial support from the National Science Foundation of China (No. 21072135) and the antifungal activity test of Chengdu Medical College (cx 20100037).

\section{REFERENCES}

1. L. Wang, Y.X. Shi and B.J. Li, Pest. Sci. Administ., 29, 24 (2008).

2. C.L. Liu, The World Pesticide, Chemical Industry Press, Beijing, pp. 117-149 (2006).

3. A.Y. Guan, H.C. Li, J.B. Zhang, X.F. Sun and L.Z. Wang, Fine Specialty Chem., issue no. 4, 24 (2012).

4. C.H. Mao, L. Huang and M.Z. Huang, Fine Chem. Intermed., 31, 4 (2001).

5. Y.L. Bai, J. Pest., 38, 1 (1999).

6. N. Fisher and B. Meunier, Pest. Manage. Sci., 61, 973 (2005).

7. X.J. Yan, S.H. Jin and F.H. Chen, J. Pest. Sci., 8, 299 (2006).

8. L.A. Ping, Fine Chem. Intermed., 33, 1 (2003).

9. D.W. Bartlett and J.M. Clough, Pest. Manage. Sci., 58, 649 (2002).

10. Y.F. Liu and Y.L. Bai, J. Modern Pest., 2, 29 (2003).

11. P. Masner and P. Schmid, J. Pest. Sci., 42, 163 (1994).

12. C.L. Liu and J.D. Li, J. Pest., 39, 1 (2000).

13. H. Sauter, W. Steglich and T. Anke, Angew. Chem. Int. Ed., 38, 1328 (1999).

14. G.S. Zhang, Pest. Manage. Sci., 24, 30 (2003).

15. P. Zhao, Q.X. Yan, X. Li and M.H. Zhang, Agrochemicals, issue no. 8, 547 (2011).

16. J.-Y. Chen, C.-C, Chen and L.-S. Wong, Acta Chim. Sinica, 29, 368 (1963).

17. J. Dong, D.H. Liao, J.S. Lou and H.J. Pi, Fine Chem. Intermed., 3725 (2007). 